\title{
The Evaluation Model of Student Decision in Using Islamic Banking: Theory of Planned Behavior Approach
}

\author{
$1^{\text {st }}$ Sugiyanto ${ }^{1}$ Jatmiko $^{1}, 2^{\text {nd }}$ Nurjannah Endah Rahayu ${ }^{1} 3^{\text {rd }}$ Dwi Hendro Widayatmoko ${ }^{2}$ \\ sugiyanto@esaunggul.ac.id ${ }^{1}$, jatmiko@esaunggula.c.id ${ }^{1}$, nurjannah.endah@esaunggul.ac.id ${ }^{1}$ \} \\ Department of Management Faculty of Economic and Business Esa Unggul University, Kebon Jeruk, \\ Jakarta, Indonesia ${ }^{1}$
}

\begin{abstract}
Research on consumer behavior has been focused more on service advertisements and so on. This study evaluates the customer decision model i using the TPB approach. The expected results from this study are first, making a decision model for the selection of Islamic banks among students by using the development of planned behavioral theory. Second is to find out whether Islamic bank selection behavior for activities is carried out with careful consideration or just following others, third is to find out the profile of potential customers of Islamic banks among University of Esa Unggul students. Using primary data by distributing questionnaires to respondents by using purposive sampling method. Data analysis using causality method using Structural Equation Modeling (SEM) and qualitative analysis is done by cross tab and mapping of respondents' answers to find out how the characteristics of potential customers of Islamic banks among students. The expected findings from the results of this study were the first evaluation of the decision model of the selection of Islamic banks among students at Esa Unggul University, the second factor which had the greatest influence in the decision on the selection of Islamic banks among students at Esa Unggul University Jakarta, the third to find out the profile potential customers of Islamic banks among Esa Unggul University students in Jakarta.
\end{abstract}

Keywords: Theory of Planned Behavior, Structural Equations Modelling, Sharia Banking, Student

\section{Introduction}

Indonesia is the largest Muslim population in the world, based on data from the Central Bureau of Statistics, the number of Indonesian Muslim population in 2012 was 207176162 people, equivalent to $87.18 \%$ of the total population of Indonesia. Regarding macroeconomics, Indonesia is a country with high economic growth. The average economic growth in Indonesia is $6.2 \%$, in 2012 with a per capita income of $\$ 3,563$. Indonesia is predicted to become one of the world leaders in 2020 with per capita income predicted to be more than $\$ 7,000$.

A large number of Muslim population in Indonesia is not comparable with the development of the Sharia Economy in Indonesia. Based on Bank Indonesia's data in 2012 the capitalization of sharia banking assets in the new Indonesia 227.711 billion rupiahs while at the same time the capitalization value of conventional commercial banks is $4,716,845$ billion rupiahs. Total public funds in Syari'ah Bank in Indonesia amounted to 3,411,188 billion 
rupiahs in September 2013 while at the same time third-party funds in banks conventional general 3,520,890 billion rupiahs. The total funds collected by Shariah banking in Indonesia as of September 2013 is equivalent to $6.57 \%$ of the total funds that can be used in conventional public banking. The same thing also happened in Malaysia, based on the research by Ahmad and Sudin (2004) the number of funds from third parties for shari'ah banking was RM 31 million ringgit while for conventional banking at the same time the number of funds from third parties was RM 381 million ringgit. The amount of funds is from third parties in the syari'ah bank, only $10 \%$ of the total banking funds as a whole.

Some research on the factors that influence Muslims in choosing sharia banking results is contradictory. In general, the research focuses on personal behavior (internal) of the respondents about the decision to choose a Shariah bank. Research conducted by Elfachmi (2012) shows that the religiosity background influences the degree of customer satisfaction and loyalty. Research conducted by Muhlis (2011) which divides the sample into three groups. The first group is the sample that saves at the Syari'ah bank solely for religious reasons. The second group is a sample that saves at Bank Syariah for reasons of religion and profits and the third is a bank customer from the non-Muslim group. The results show that the religiosity factor only affects the savings behavior for first group customers. This shows that some of the people claim to act rationally in saving, not seeing regarding religion but also on the profit side.

Research conducted by previous research shows that attitudes, subjective norms, perceived control, religiosity, income, education and age influence the intention to save at the Shariah bank. This study supports the results of previous research concerning customer selection criteria shows that the religious factor (Shariah Attribute Complaint attribute) is the first rank while the profitability factor is the second rank.

\section{Literature Review}

Behaviorists exist as a reaction to introspectionism which analyzes human behavior based on subjective reports that appear, as well as reactions to psychoanalysis theories that discuss the invisible subconscious. Behaviorism wants to analyze human behavior that appears and can be measured, described and predicted. According to Peter and Olson, translated by Diah Tantri Dwiandini said that behavior refers to consumers' physical actions that can be directly observed and measured by other parties.

Theory of Planned Behavior was developed by Ajzen in 1985; this theory is a development of the Theory of Reasoned Action, the model of the planned Behavioral Theory can be described as shown in Figure 1.

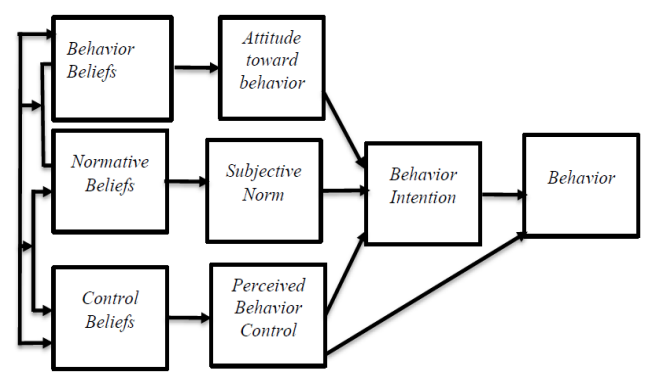


Figure 1. Theory of Planned Behavior

Human behavior is influenced by interest, while three factors influence this interest, the first is attitude towards behavior, the second is subjective norms adopted by individuals and the third is perceived behavior control which explains how individuals it can control its behavior

Attitude towards behavior is a thorough evaluation of a person in behaving (Jogiyanto, 2007). Attitudes toward behavior are based on a belief in behavior that connects the interest to behave according to the expected results. Behavioral belief is a subjective probability of an individual that the behavior carried out will produce results as expected. Although each has many behavioral beliefs, few are easily accessed and explained at certain times. It is assumed that beliefs behave in combination with subjective values that are believed to affect attitudes toward behavior. The results of evaluation of the results of behavior by individuals contribute to determining attitudes in the proportion of subjective individual probabilities to give results as expected

Belief can indicate an action or behavior, even though information about something that is believed to be unlimited is limited, but only some information is believed that can make certain attitudes and behavior. Attitude toward a behavior is the degree of positive or negative value of a behavior outcome. According to the expectation value model, attitudes toward behavior are determined by a combination of behavioral beliefs that are linked to various possible outcomes and other attributes, especially the magnitude of the confidence level provided and the weight of the results of the evaluation of the expected results.

The components of the planned behavioral theory are as follows:

\subsection{Attitude toward Behavior}

Attitude is an individual's internal component that is related to an object. Attitudes have an important role because they can determine what actions or behaviors an individual does without being influenced by factors outside the individual. Fishbein and Azjen define attitudes as the number of affections or feelings to accept or reject a particular object or behavior. Factors that influence behavior are:
1. Lifestyle
2. Knowledge
3. Price
4. Personal Experience
5. Mass Media

\subsection{Subjective Norm}

Subjective norms are a person's perception of the beliefs of others that affect interest in doing or not doing the behavior being considered (Jogiyanto, 2007). Normative beliefs about perceived behavior refer to how important the reference group is like a spouse, family or friends. Research conducted on doctors, supervisors or worker helpers will show different results. It is assumed that normative beliefs will be combined with the motivation of individuals to follow different references that will form the individual's subjective norms. In particular, the motivation to adhere to the reference group contributes directly to subjective norms. The influence of the reference group is equal to the subjective probability that the person referred will think about doing a certain behavior. 
Subjective norms are social pressures felt by individuals to be involved or not involved in behavior. This subjective norm is external to the individual. This norm is the second determinant of intentions that relate directly to individuals or groups that become a reference in behaving. The subjective norm factor that is considered to influence interest in behaving is:

1. Family

2. Reference Group

3. Friend

The study conducted by Shah Alam and Sayuti (2011) stated that subjective norms have a positive effect on the intention to buy halal products. The results of this study were also strengthened by previous research which stated that subjective norms proxied by mutual commitment among friends had a positive effect on the intention to make purchases online.

Cheng and Chu (2014) in his study stated that subjective norms influence the intention to behave and actual behavior. Cheng and Chu also stated that the use of the theory of planned behavior is better than social cognitive theory to predict intention to behave.

\subsection{Perceived Behavior Control}

This behavior control is the ability of individuals to control themselves or refrain from certain behaviors. Behavioral control is determined by the control of beliefs about the existence of factors that can help or hinder behavior and the power to do or not do a particular behavior. Factors that influence control of behavior are:

1. Locus of Control

2. Personal Perception

3. Self Efficacy

Attitudes towards behavior, subjective norms, perception control influence and can explain the relationship to behavioral intentions. Individual intentions and self-assessment are the best predictors of individual behavior. Martin and Kulinna (2004) show that the use of the theory of planned behavior with attitudes toward behavior variables, behavioral control influences students' intention to play an active role in physics. The ability to explain its effect on dependent variables is $59 \%$. The approach with the behavioral theory that is planned to explain the intentions of the results is better than the theory of self-efficacy

\subsection{Intention Behavior}

The intention to behave or intention to behave is a proposition that connects itself to the action that will come. The intention is a plan to perform actions or behavior specifically to achieve goals. Factors that influence behavioral intention are:

1. Referential Intentions

2. Preferential Intention

3. Exploratory Intentions

The intention in the theory of planned behavior is influenced by attitudes toward behavior, subjective norms and perception control. Intention also becomes a moderating variable on behavior variables. A previous study taking samples of students in Kenya shows that purchase intentions are influenced by attitudes toward behavior directly. While subjective norms and gender as moderating variables do not influence the purchase intention.

The results of the previous research show that attitudes toward behavior proxied by risk perception, value perception and subjective norm variables influence interest. Intention variables affect actual behavior

Some studies of the low intention of Muslim communities to utilize Islamic banks in particular or sharia-based investments in Indonesia, the first is the lack of understanding of the 
community about sharia-based activities and cannot distinguish the concept of sharia investment with conventional investments. Secondly, there is no special treatment for Islamic banking in business competition, the limited number of capital owned by Islamic banks makes it difficult to face business competition

Studies in Islamic banking can be grouped into two groups. The first category is the study from the internal side of sharia banking itself. This study includes the implementation of the promotional mixes such as promotional advertisements and so on, as well as performance such as the size of the profit ratio for customers or the services provided by Islamic banking to its customers. Research conducted by Siddiqui (2007) criticized the lack of attention of the government, especially in Muslim countries and the lack of serious Islamic banking itself in promoting the community to develop Islamic banking with the concept of profit sharing. This lack of knowledge, especially for prospective customers, creates a low intention of the community to invest/save in Islamic banks

Maski (2012) shows that service variables and trust in banks have the greatest influence on consumer decisions in using Islamic banking. The results of this study are the same as the results of Astuti et al. (2012) and friends of the BRI Syariah Cab. Surakarta which shows that service quality is a major factor in the selection of Islamic banks. The implications of the results of the two studies show that sharia banking consumers in Indonesia want the quality of Islamic banking services to be the same as conventional banking. The normal consequence of the results of the study is clear that the policy of sharia banking marketing in Indonesia replicates from conventional banking marketing policies and strategies

The second research on Islamic banking emphasizes the psychological aspects of customers. This assumes that for Muslims investing both in the banking sector and in the capital market is not solely seeking profit but rather towards halal investment. This is what causes the religious factor to be very dominant for Muslim investors. Customer psychology approach becomes very important to be highlighted by Islamic banking in attracting potential investors/customers. By changing its marketing strategy, it is expected that Islamic banking not only increases the number of customers but also creates loyal customers.

Previous research conducted a study of 350 customers from 5 Islamic banks in Pakistan, and the results showed that attitudes toward Islamic banking would affect service quality and satisfaction which in turn will increase customer' trust and loyalty of sharia banking customers. The results of this study were reinforced by research of banking customers in Malaysia conducted by Asjraf Wajdi Dasuki and Nurdianawati Irwani Abdullah about the decision of customers to use Islamic banking, the results show that the most influential factor is customer satisfaction which is strongly influenced by the quality of bank services in this case including how Islamic banks treat their customers. From the two studies above it is clear that investment behavior is strongly influenced by factors within the investor (internal) and from outside the investor (external / Islamic bank).

Research on investor behavior in Indonesia conducted by Elfachmi (2012) shows that the religiosity background influences the degree of satisfaction and degree of customer loyalty. Research conducted by Muhlis (2011) who divided the sample into three groups. The first group is a sample that saves in a Sharia bank solely for religious reasons. The second group is a sample that saves at Bank Syariah for religious reasons and profits, and a sample of the third group is a bank customer from a non-Muslim group. The results show that religiosity factors only affect saving behavior for first group customers. This shows that some of the Muslim community behaves rationally in saving, not only regarding religion but also in profit, and it can be concluded that among Muslims in Indonesia there are still differences in perceptions of Islamic banks. 
Previous research shows that attitudes, subjective norms, perceived control, religiosity, education income and age affect the intention to save in Islamic banks.

\section{Research Methodology}

\subsection{Type and Design of Research}

The type of research used is explanatory research with non-experimental research designs, explaining the causality relationship between dependent/indigenous variables (Y). The dependent variable is the behavior of choosing Islamic banks with independent variables of intention to behavior, attitudes toward behavior, subjective norms, control of perceived behavior as independent/exogenous variables $(\mathrm{X})$.

This study describes the behavior of customers to make decisions by answering questions asked in the questionnaire to perceive their behavior. The research method used is a survey method, by collecting respondents' data to explain, comparing their knowledge, intentions or behavior. By using primary data which is done by distributing questionnaires to respondents.

\subsection{Analysis Unit}

The unit of analysis is the group or group members who are examined in the study. In this study, the unit of analysis was students from Esa Unggul University students in Jakarta

\subsection{Types and Sources of Data}

The source of data in this study is primary data, by collecting data directly by distributing questionnaires to respondents. Data in the form of opinions, attitudes, experiences, behaviors or characteristics of respondents individually. This data is quantified by changing into a Likert scale.

\subsection{Population, Sample and Sampling Technique}

a. Population.

The population is a set of research objects with the same characteristics. Population In this study were Esa Unggul University Students in Jakarta.

b. Research Sample.

The research sample is part of the population taken to be used as respondents. A sample survey is a procedure to retrieve and determine the part of the population that will be examined by its characteristics (Cooper et al. 2006). According to Heir and friends (1998), the number of samples is $5-10 \times$ the number of indicators. While according to Ferdinand (2003) using Maximum likelihood estimation (MLE), the number of samples needed is 100-200 respondents. In this study, the number of samples used was 150 respondents.

c. Sampling technique.

The sampling technique in this study uses non-probability sampling, this technique is used if the population is not known, or the criteria of the research subject have been determined in advance (Sekaran and Bougie, 2016), with a purposive sampling method of sampling techniques that are non-probability sampling using criteria certain to facilitate the sampling process. The criteria used for the sample in this study are:

1) Active Esa Unggul University Students at Even Semester 2016/17 Academic Year.

2) Moslems. 
3) Being at the location when distributing questionnaires

\subsection{Research Model}

The research model used in this study is as shown in Figure 2.

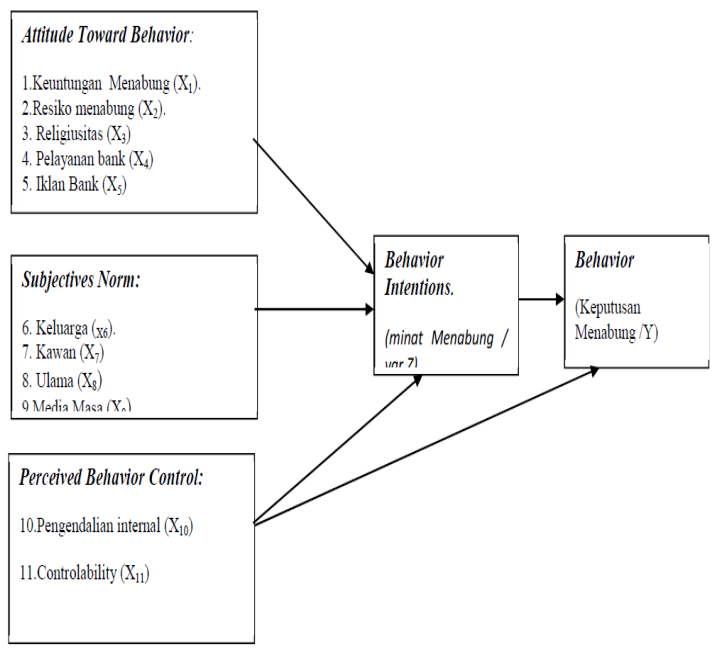

Figure 2. Research model

\subsection{Data Analysis Methods}

1. Analysis of Validity and Reliability

This study uses secondary data, so before the research is carried out, it is necessary to test the validity and reliability.

2. Validity Test

Validity test is used to test whether the questionnaire used can measure data validity or not. The validity test uses product moment correlation

$$
r_{X Y}=\frac{N \sum X Y-\left(\sum X\right)\left(\sum Y\right)}{\sqrt{\left\{N \sum X^{2}-\left(\sum X\right)^{2}\right\}\left\{N \sum Y^{2}-\left(\sum Y\right)^{2}\right\}}}
$$

Where

$\mathrm{N}=$ Amount of Data

$\mathrm{X}=$ independent variable.

$\mathrm{Y}=$ variable depends

Data is valid if the results of data analysis show $\operatorname{Sig} \leq \alpha$. or vice versa. The level of confidence used is $95 \%$.

3. Reliability Test

Reliability tests are used to test the stability and consistency of questionnaires to predict parameters based on concepts/theories (Sekaran and Bougie, 2016). Reliability testing of this questionnaire uses Cronbach Alpha. 


$$
\left.C A=\left[\frac{k}{k-1}\right] 1-\frac{\sigma_{b}^{2}}{\sigma_{t}^{2}}\right]
$$

$\mathrm{CA}=$ Cronbach's Alpha coefficient.

$\mathrm{K}=$ number of questions in items

Sigma $\mathrm{b}$ squared $=$ question variance

Sigma t squared $=$ total variance

Data is reliable if the results of data analysis are more than $0.615(\geq 0.615)$

4. Cross Tab

Make a tabulation and mapping answers from respondents to then conclude the tendency of respondents' answers. From the demographic data, respondents can be influenced by the tendency of the respondent's behavior.

5. Quantitative Analysis

Quantitative analysis is carried out using SEM (Structural Equation Modeling). To test the hypothesis of the effect of the independent variable on the dependent variable. The results of the regression equation that are expected later are as follow.

Model 1

$$
\mathrm{Z}=\mathrm{a}+\mathrm{b}_{1} \mathrm{X}_{1}+\mathrm{b}_{2} \mathrm{X}_{2}+\mathrm{b}_{3} \mathrm{X}_{3}+\mathrm{b}_{4} \mathrm{X}_{4}+\mathrm{b}_{5} \mathrm{X}_{5}+\ldots \ldots \ldots \ldots \ldots \ldots \ldots+\mathrm{b}_{11} \mathrm{X}_{11}+\varepsilon
$$

Savings intention $(Z)$ is influenced using Attitudes towards behavior proxied by:

1) Degree of benefit (X1)

2) Risk Degrees (X2)

3) Degree of Religiosity (X3)

4) Bank services (X4)

5) Bank advertisement (X5).

Subjective norms proxied by:

1). Family influence (X6).

2). Friend influence (X7).

3) Influence of religion leaders/ulama (X8).

4). Influence of mass media (X9).

Perceived behavioral control proxied by:

1). Internal self-control (X10).

2). External / controllability (X11).

$\mathrm{Y}=\mathrm{a}+\mathrm{b} 10 \mathrm{X} 10+\mathrm{b} 11 \mathrm{X} 11+\mathrm{b} 12 \mathrm{Z}+\varepsilon$

The decision of saving behavior (Y) is influenced using Perceived behavioral control proxied by:

1) Internal self-control (X10).

2) External / controllability control (X11).

3) Intention to save $(Z)$.

\subsection{Definition of Operational Variables and Variable Measurements}

This study uses variables and measuring instruments as follows. 
1. Attitude towards Behavior

Attitudes toward behavior can be interpreted as positive or negative beliefs and feelings, as a result of evaluation if individuals do or do not do the desired behavior (Jogiyanto, 2007). According to research by Zhang et al. (2015) attitudes towards this behavior are influenced by environmental knowledge and moral obligation.

In this study attitudes toward behavior were proxies with;

1) Knowledge of the benefits of saving (investment) in a bank as X1.

2) Knowledge about risk saving in the bank as $X 2$.

3) Degree of Religiosity. This aspect measures the investor's understanding of the investment concept in sharia as X3.

4) Bank services. Measuring how important aspects of the service of Islamic banks according to customer perception (X4).

5) Bank advertising. How much advertising is done by Islamic banking in influencing the attitudes of customers (X5)

2. Subjective Norms

Subjective norms are social norms adopted by individuals that will influence their behavior. The form of subjective norms is social pressure to do or not do something. In this study, subjective norms are proxied by:

1) Friend's opinion as $X 6$.

2) Family income as $X 7$.

3) The approach of religious leaders (ulama / religious leaders) as X8.

4) Information from Mass Media (X9)

3. Perceived Behavior Control

Perceived behavioral control can be interpreted as the ease or difficulty of an individual to control his perception of behavior. According to Ajzen, there are two factors in perceived behavioral control, namely factors from the individual's internal or self-efficacy and factors outside the individual or locus of control. In this study perceived behavioral control was proxied by:

1) Internal control or self-efficacy $(\mathrm{X} 10)$

2) External Control or locus of control (X11)

4. Behavioral Intention or variable $\mathrm{Z}$

Intention can be interpreted as a desire to conduct behavior. This intention is not static but can change over time.

Intention to behavior is a function of control of behavior, attitudes toward behavior and subjective norms. According to Chiffman and Kanuk in Riska Septifani et al. (2014) the intention to buy is a psychological feeling that arises because of feelings (affective) and mind (cognitive) of the goods or services that you want to buy.

This intention variable became an intervening variable at the time of analysis between attitude variables, subjective norms and perceived control of behavioral variables.

5. Behavior or Variable Y

Behavior is a function of intentions towards behavior, attitudes, subjective norms and perceived behavioral control. Intention to strong behavior will encourage the emergence of strong behaviors as well. According to the previous research results, there is a positive and very strong correlation between intentions and recycling behavior. 
All data in this study are measured ordinal scale, where the answers from the respondents are assumed by using a linkers scale. This study used an error of $5 \%(\alpha=0.05)$, or the confidence level used was $95 \%$. Hypothesis testing is done using a two-sided test (two tails).

Acknowledgements. This paper in conjuction with the The 1st International Conference Recent Innovation (ICRI) 2018.

\section{References}

[1] Ahmad, N., and Sudin, H. Perception of Malaysian Corporate Customers Toward Islamic Banking Products \& services. International Journal of Islamic Financial Services, 3(4) (2004).

[2] Ajzen, I. Perceived behavioral control, self-efficacy, locus of control, and the theory of planned behavior 1. Journal of applied social psychology, 32(4): 665-683 (2002).

[3] Al-Tamimi, H. A. H. Factors influencing individual investor behavior: an empirical study of the UAE financial markets. The Business Review, 5(2): 225-233 (2006).

[4] Astuti, S. P., Wilasari, W., and Utami, D. E. Meningkatkan Kualitas Pelayanan Di Bank Syariah Penelitian Dengan Fuzzy Servqual Dan Dimensi Carter. INTERNATIONAL RESEARCH JOURNAL OF BUSINESS STUDIES, 2(1) (2012).

[5] Cheng, P. Y., and Chu, M. C. Behavioral factors affecting students' intentions to enroll in business ethics courses: A comparison of the theory of planned behavior and social cognitive theory using self-identity as a moderator. Journal of Business Ethics, 124 (1): 35-46 (2014).

[6] Cooper, D. R., Schindler, P. S., and Sun, J. Business research methods, Vol. 9. New York: McGraw-Hill Irwin (2006).

[7] Elfachmi, A. K. Analisis Pengaruh Latar Belakang Religiusitas, Tingkat Sosial Ekonomi dan Rasionalitas Terhadap Kepuasan serta Loyalitas Nasabah Bank BNI Syari'ah Cabang Malang. (Disertasi). DISERTASI dan TESIS Program Pascasarjana UM (2012).

[8] Ferdinand, A. Structural equations Modelling dalam penelitian Manajemen: Aplikasi Model Model rumit dalam penelitian untuk Tesis dan Desertasi Doktor, $2^{\text {nd }}$ edition. Semarang: UNDIP (2003).

[9] Jogiyanto, H. M. Sistem informasi keperilakuan. Yogyakarta: Andi Offset (2007).

[10] Martin, J. J., and Kulinna, P. H. Self-efficacy theory and the theory of planned behavior: Teaching physically active physical education classes. Research Quarterly for Exercise and Sport, 75(3): 288-297 (2004).

[11] Maski, G. Analisis keputusan nasabah menabung: Pendekatan komponen dan model logistik studi pada bank syariah di Malang. Journal of Indonesian Applied Economics, 4(1) (2012).

[12] Muhlis. Perilaku menabung di Perbankan Syariah di Jawa Tengah. Semarang: Universitas Diponegoro (2011).

[13] Septifani, R., Achmadi, F., and Santoso, I. Pengaruh green marketing, pengetahuan dan minat membeli terhadap keputusan pembelian. Jurnal Manajemen Teknologi, 13(2): 201-218 (2014).

[14] Siddiqui, S. A. April). Establishing the Need and Suggesting a Strategy to Develop Profit and Loss Sharing Islamic Banking (PALSIB). In IIU Malaysia Conference on Islamic Banking and Finance at Kuala Lumpur (2007,

[15] Shah Alam, S., and Mohamed Sayuti, N. Applying the Theory of Planned Behavior (TPB) in halal food purchasing. International journal of Commerce and Management, 21(1): 8-20 (2011).

[16] Sekaran, U., and Bougie, R. Research methods for business: A skill building approach. John Wiley \& Sons (2016).

[17] Zhang, D., Huang, G., Yin, X., and Gong, Q. Residents' waste separation behaviors at the source: Using SEM with the theory of planned behavior in Guangzhou, China. International journal of environmental research and public health, 12(8): 9475-9491 (2015). 